\title{
Behavior of Sunflower Irrigated With Salt Water and Nitrogen Fertigation
}

\author{
Daivyd Silva de Oliveira ${ }^{1}$, Edvania Pereira de Oliveira ${ }^{2}$, Thiago Jardelino Dias $^{3}$, Hemmannuella Costa Santos ${ }^{4}$, \\ Álvaro Carlos Gonçalves Neto ${ }^{3}$, Francisco Hélio Alves de Andrade ${ }^{5} \&$ Welliton Barros de Magalhães ${ }^{3}$ \\ ${ }^{1}$ Programa de Pós-Graduação em Agronomia, Universidade Federal de Santa Maria, Santa Maria, RS, Brazil \\ ${ }^{2}$ Graduada em Ciências Agrárias, Universidade Federal da Paraíba, Bananeiras, PB, Brazil \\ ${ }^{3}$ Departamento de Agricultura, Universidade Federal da Paraíba, Bananeiras, PB, Brazil \\ ${ }^{4}$ Departamento de Desenvolvimento Educacional, Instituto Federal de Educação, Ciência e Tecnologia de \\ Pernambuco, Vitória de Santo Antão, PE, Brazil \\ ${ }^{5}$ Programa de Pós-Graduação em Agronomia (Fisiologia Vegetal), Universidade Federal de Lavras, Lavras, MG, \\ Brazil \\ Correspondence: Daivyd Silva de Oliveira, Programa de Pós-Graduação em Agronomia, Universidade Federal \\ de Santa Maria, Santa Maria, RS, Brazil. E-mail: daivydoliver@hotmail.com
}

Received: January 10, 2019

Accepted: February 12, $2019 \quad$ Online Published: April 15, 2019

doi:10.5539/jas.v11n5p342

URL: https://doi.org/10.5539/jas.v11n5p342

\begin{abstract}
The sunflower (Helianthus annus L.) crop has been gaining prominence in wastewater research due to its relevance to the production of edible oil, biodiesel and ornamental and decorative material. In the field of floriculture, the crop has been emerging as an alternative offer of a short-cycle product, with contrasting colors and easy identification by the consumer. The objective of this work was to evaluate the different electrical conductivities of water associated with nitrogen fertigation rates on the vegetative, physiological and productive behavior of ornamental sunflower. The experimental design was completely randomized, in a factorial scheme $6 \mathrm{x} 4$, referring to six levels of electrical conductivity of water (ECa of $0.5,1.5,2.5,3.5,4.5$ and $5.5 \mathrm{dS} \mathrm{m}^{-1}$ ) and four nitrogen fertigation rates, with one control and the other three applications performed every 10, 20 and 30 days after emergence (DAE), with five replications, totaling 120 experimental units. The variables analyzed were: stem diameter, root length, chlorophyll a, b and total chlorophyll content, fresh and dry phytomass of shoots, roots and total phytomass, seed mass and capitulum mass. The salinity negatively affected the physiological variables, growth and productivity evaluated, decreasing with increasing electrical conductivity of irrigation water $\left(\mathrm{dS} \mathrm{m} \mathrm{m}^{-1}\right)$. Nitrogen fertigation at 10 days after emergence resulted in an increase in the stem diameter of sunflower plants.
\end{abstract}

Keywords: Helianthus annus L., salt stress, nitrogen; ornamental

\section{Introduction}

Sunflower (Helianthus annuus L.) is an annual dicotyledon belonging to the family Asteraceae, originating in North America (Zobiole et al., 2010). This species, besides being an important option for the agricultural producer in systems involving crop rotation or succession, presents excellent oil quality and yield, much appreciated in animal feed as a source of protein, as well as in the production of biofuels, being a crop which also aims at the commercialization of flowers (Silva et al., 2011).

The ornamental sunflower can be grown in any region of the Brazil, presenting it self as an alternative to the floriculture sector, for being a crop without great management difficulties. The crop has broad climatic adaptability, high tolerance to drought, cold and heat, becoming less influenced by latitude, altitude and photoperiod (Zobiole et al., 2010).

The semi-arid region of the Brazilian northeast is commonly affected by irregular rainfall, due to its insufficiency and poor distribution throughout the year, such that these facts are one of the most limiting factors to agricultural productivities, significantly impairing crop yield. These characteristics justify the need to resort to 
irrigation, aiming at mitigating and correcting the problems arising from inadequate water supply in agriculture (Silva et al., 2011), increasing the productivity of grains, oil or dry mass in crops under irrigation.

Notwithstanding, in the Brazilian semi-arid region, due to the scarcity of surface water sources, the water used for irrigation purposes by rural families is obligatorily of subterranean origin (crystalline basement), which in most cases presents restrictions of use for having high salt concentration, especially sodium, determining production limitations, with damaging effects to plants in their different phases, in addition to causing problems of edaphic and environmental degradation, leading to problems of great proportions in the productivity of agricultural crops (Andrade et al., 2012; Costa et al., 2013). The saline water as well can to change the soil aggregate structure, reduce the permeability, increase the salinity and restrict the water, nutrients and oxygen availability (Russo, 2005; Wong et al., 2008).

Nitrogen $(\mathrm{N})$ is the most required nutrient for the greatest diversity of cultivated plants, because the development is highly dependent on the availability of this nutrient due to its functions in plant metabolism, participating as a constituent of the molecule of chlorophyll, nucleic acids, amino acids and proteins (Taiz \& Zeiger, 2012).

In view of the above, the objective of this work was to evaluate the different electrical conductivities of irrigation water associated with nitrogen fertigation rates on the vegetative, physiological and productive behavior of ornamental sunflower.

\section{Materials and Methods}

The experiment was conducted in a screened greenhouse, between October 2014 and February 2015, in the Agricultural Sector of the Center for Human, Social and Agrarian Sciences (CCHSA) of the Federal University of Paraíba (UFPB), Campus III, in Bananeiras-PB, located in the microregion of Brejo Paraibano, at $6^{\circ} 45^{\prime} \mathrm{S}$ latitude and $35^{\circ} 37^{\prime} \mathrm{W}$ longitude, with a hot and humid (tropical rainy) climate.

The experimental design was completely randomized, in a factorial scheme $6 \times 4$, referring to the irrigation water salinity in six electrical conductivities of water (ECa of $0.5,1.5,2.5,3.5,4.5$ and $5.5 \mathrm{dS} \mathrm{m}^{-1}$ ) and four fertigation times with nitrogen in the amount of $60 \mathrm{~kg} \mathrm{ha}^{-1}$, being one control (without fertigation) and fertigation performed at 10, 20 and 30 days after emergence (AED), with five replications. The source of nitrogen was utilized by urea.

The experimental units were composed of pots with a volumetric capacity of $1.3 \mathrm{dm}^{3}(15 \mathrm{~cm}$ high), filled by a substrate formed by vegetal soil and bovine manure, in the ratio of $3: 1(\mathrm{v} / \mathrm{v})$, (Table 1$)$.

Table 1. Chemical and fertility characterization of the substrate used in the experimental units

\begin{tabular}{|c|c|c|c|c|c|c|c|c|c|c|c|}
\hline \multicolumn{12}{|c|}{ Chemical Attributes } \\
\hline $\mathrm{pH}_{(\mathrm{H} 2 \mathrm{O})}$ & $\mathrm{P}$ & $\mathrm{K}^{+}$ & $\mathrm{Na}^{+}$ & $\mathrm{H}^{+}+\mathrm{Al}^{3+}$ & $\mathrm{Al}^{3+}$ & $\mathrm{Ca}^{+}$ & $\mathrm{Mg}^{2+}$ & SB & $\mathrm{CEC}$ & $\mathrm{V}$ & O.M. \\
\hline & $\mathrm{mg} \mathrm{dm}{ }^{-1}$ & - ----- & 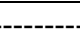 & ----------. & $\mathrm{cmol}$ & $m^{-3}--$ & - & ----- & ------- & $\%$ & $\mathrm{~g} \mathrm{~kg}^{-1}$ \\
\hline 6.51 & 80.43 & 0.84 & 0.22 & 1.81 & 0.0 & 4.02 & 2.15 & 7.23 & 9.04 & 79.9 & 38.69 \\
\hline
\end{tabular}

Note. $\mathrm{pH}$ in water; $\mathrm{SB}=$ Sum of Bases $\left(\mathrm{Ca}^{2+}+\mathrm{Mg}^{2+}+\mathrm{K}^{+}+\mathrm{Na}^{+}\right) ; \mathrm{CEC}=$ Cation Exchange Capacity $\left[\mathrm{SB}+\left(\mathrm{H}^{+}+\right.\right.$ $\mathrm{Al}^{3+}$ ); $\mathrm{V}=$ Saturation by exchangeable bases (SB/CEC)100; O.M. = Organic Matter.

The seeding was carried out in October 2014, and the seeds were sown directly in the pot. The seeds began their emergence 5 days after sowing. When they reached $10 \mathrm{~cm}$ in height, thinning was performed, leaving a single plant per experimental unit. The variety used in the experiment was the cultivar "Sol Noturno".

During the experimental period, the temperature and humidity of the air were measured daily with a digital termo-hygrometer installed in the experimental area, at the height of the benches (Table 2).

Table 2. Average of the temperature e humidity maximum and minimum of the conduction environment of the experiment

\begin{tabular}{lll}
\hline & Maximum & Minimum \\
\hline Temperature $\left({ }^{\circ} \mathrm{C}\right)$ & 32.21 & 22.85 \\
Humidity $(\%)$ & 91.3 & 44.4 \\
\hline
\end{tabular}


Irrigation was performed daily at the end of the afternoon, where the soil was initially maintained at pot capacity (PC) with the intention of to guarantee the emergence process and the development of the plants. Subsequently, the water management was performed by weighing the pots, in order to provide the volume of evapotranspirated water in the previous 24 hours, as well as by monitoring the replacement through the actual evapotranspiration of the crop, estimated for each stage of plant development from the reference evapotranspiration (ETo) and the crop coefficient $(\mathrm{Kc}), \mathrm{ETc}=\mathrm{ETo} \cdot \mathrm{Kc}$, obtained by an evaporimeter installed in an agrometeorological station (AESA) near the experimental area.

The preparation of the water with the respective saline levels (ECa) was performed weekly (Figure 3), using the $\mathrm{NaCl}, \mathrm{CaCl}_{2} \cdot 2 \mathrm{H}_{2} \mathrm{O}$ and $\mathrm{MgCl}_{2} \cdot 6 \mathrm{H}_{2} \mathrm{O}$ salts, in the ratio of $7: 2: 1$, following the relationship between $\mathrm{ECa}$ and concentration $\left(\mathrm{mmol}_{\mathrm{c}} \mathrm{L}^{-1}=\mathrm{EC} \times 10\right)$, from Rhoades et al. (2000).

Nitrogen fertilization occurred exclusively via fertigation. The fertilizer used was urea, applying the amount of $60 \mathrm{~kg} \mathrm{ha}^{-1}$ to each treatment $(0,10,20$ and $30 \mathrm{DAE})$. The control related to the cultivation (weeds and elimination of lateral shoots) was also carried out throughout the production period of the sunflower plants.

The analyzed variables were growth (stem diameter and root length), chlorophyll content (chlorophyll $a, b$ and total chlorophyll), phytomass variables (fresh mass of shoots, roots and total fresh mass; dry mass of shoots, roots and total dry mass) and production variables (seed mass and capitulum mass).

The results were submitted to analysis of variance by the $\mathrm{F}$ test at $5 \%$ probability and, in the cases of significance, polynomial regression analysis was performed (Banzatto \& Kronka, 2006). For data analysis, the statistical software ASSISTAT version 7.7 beta was used.

\section{Results and Discussion}

From the regression analyses for plant stem diameter as a function of the electrical conductivity of water (ECa) under different periods of nitrogen fertigation (Figure 1), it is observed that the combination of the different salinities of irrigation water with the addition of nitrogen fertigation at $10 \mathrm{DAE}$ provided an increase in the stem diameter of ornamental sunflower plants. These results resemble those found by Andrade et al. (2012) that analyzing the quality of sunflower flowers bottled in a greenhouse verified the diameter of the middle stem to cultivate 'Night Sun' of $8.32 \mathrm{~mm}$; and Santos Júnior et al. (2016) in experiment with hydroponics of low cost under levels of salinity observed diameter of the average stem of $7.7 \mathrm{~mm}$ for the same cultivar. For Rodrigues et al. (2012), a more vigorous stem means higher stock contents that contribute to greater resistance to transport and greater post-harvest durability, it being desirable that the stems have sufficient diameter to sustain their size and the chapter (Curti et al., 2012), also emphasizing its ecological function, making it difficult to break the stems in regions where there is a strong intensity of winds. Ivanoff et al. (2010), using nitrogen application in three sunflower cultivars in the Roraima savanna, observed mean values of $12.2 \mathrm{~mm}$, differing from the present experiment, which, independently of the nutritional concentration tested, are within the range of 5 to $15 \mathrm{~mm}$, indicated as an acceptable quality standard by Grieve and Poss (2010).

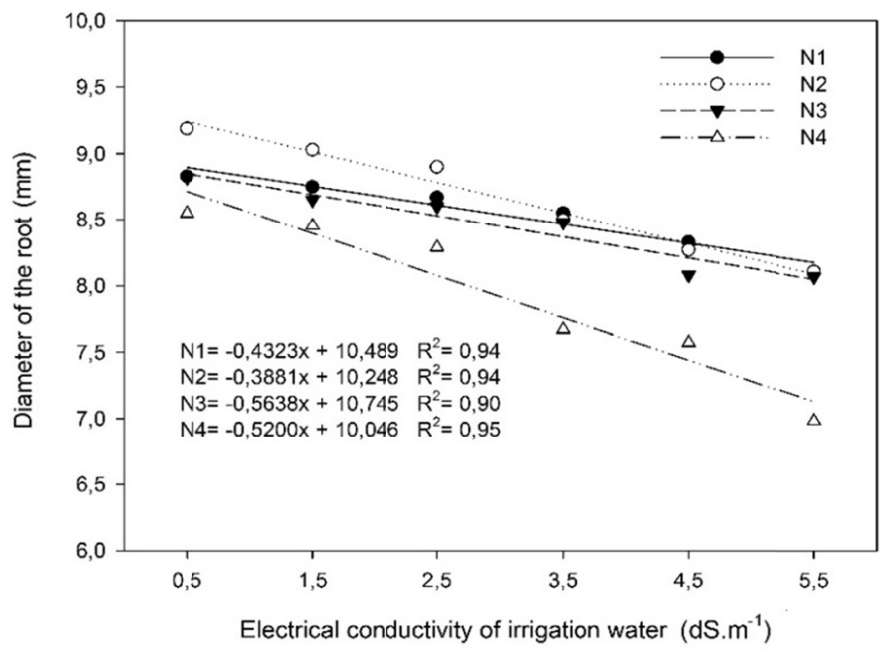

Figure 1. Stalk diameter of ornamental sunflower plants irrigated with saline water and nitrogen fertilization to the $0(-)$, to the $10(---)$, to the $20(\cdots .$.$) and to the 30(-\cdots-$.$) days after emergence (DAE)$ 
Sunflower plants irrigated with saline water presented lower root growth as the electrical conductivities increased, reducing root growth by approximately $86 \%(23 \mathrm{~cm})$ (Figure 2). The results showed that there were no significant effects for the nitrogen fertirrigation treatment for this variable. These data differ from Houle (2001), where no differences were found in the root phytomass content when Aster laurentianus plants were grown under different salt concentrations. The growth inhibition caused by progressive salt stress may be related to energy irregularity due to the increase in soil salinity levels, and may go beyond a simple decrease in soil water potential, including leading to cellular injury, caused by oxidative stress in the plant (Garcia et al., 2007).

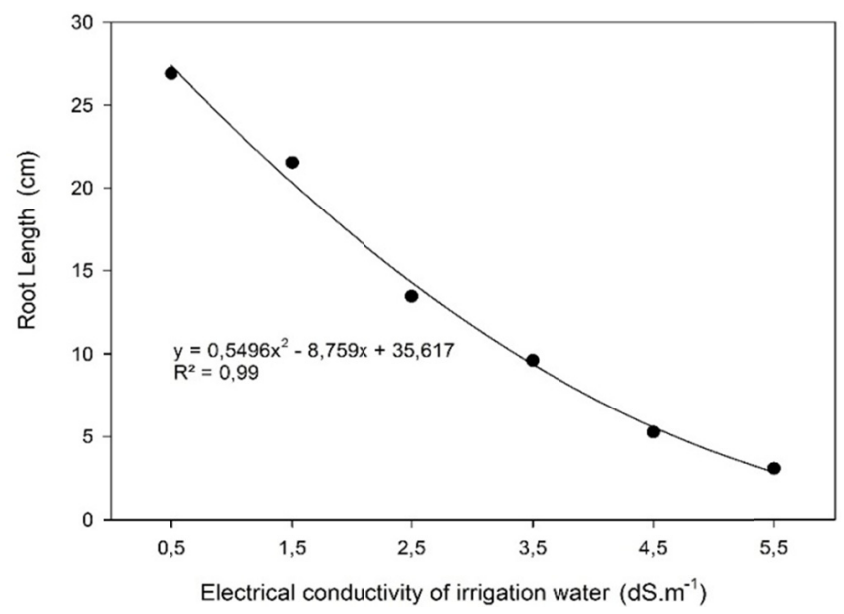

Figure 2. Root length of ornamental sunflower plants irrigated with saline water

The chlorophyll a content decreased with increasing electrical conductivity of water (Figure 3), where nitrogen fertigation rates showed similar behavior, except for 10 DAE wich showed values lower than the others. However, the fertigation at $30 \mathrm{DAE}$ outweighed the other treatments. High concentrations of $\mathrm{NaCl}$ increase the chlorophyll degradation via chlorophyllase activity, and decrease its synthesis, due to nitrogen competition with other compounds, such as proline (Ibarra \& Maiti, 1995). Regarding nitrogen fertigation, the application periods presented no statistical differences, except for the fertigation at $20 \mathrm{DAE}$, which showed higher chlorophyll a contents in the comparison between the nitrogen applications.

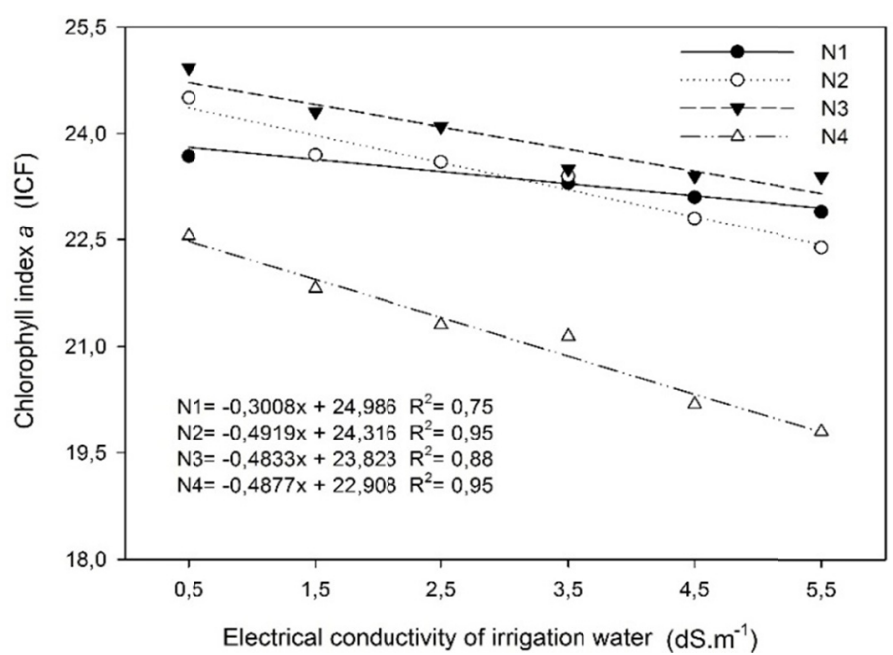

Figure 3. Chlorophyll index $a$ under nitrogen fertigation to the $0(-)$, to the $10(---)$, to the $20(\cdots \cdots)$ and to the 30 $(-\cdots-\cdot)$ days after emergence (DAE) in ornamental sunflower plants irrigated with water saline

With the increase of ECa, the chlorophyll b content decreased (Figure 4). This is related to the decrease of photosynthesis. According to Santos (2005), chlorophyll degradation can cause a considerable reduction in the photosynthetic rate and, as a consequence, a reduction in productivity. Nitrogen fertigation at 30 DAE provided 
lower contents of chlorophyll $b$ among the applications. This may have occurred due to the late application of nitrogen when the plant was already in an advanced stage of development. However, the applications performed at 10 and 20 DAE provided the best contents of chlorophyll b. Ivanoff et al. (2010) observed that the application of $\mathrm{N}$ up to 20 DAE provided better development of sunflower, and that applications from 20 DAE did not present good results for this crop.

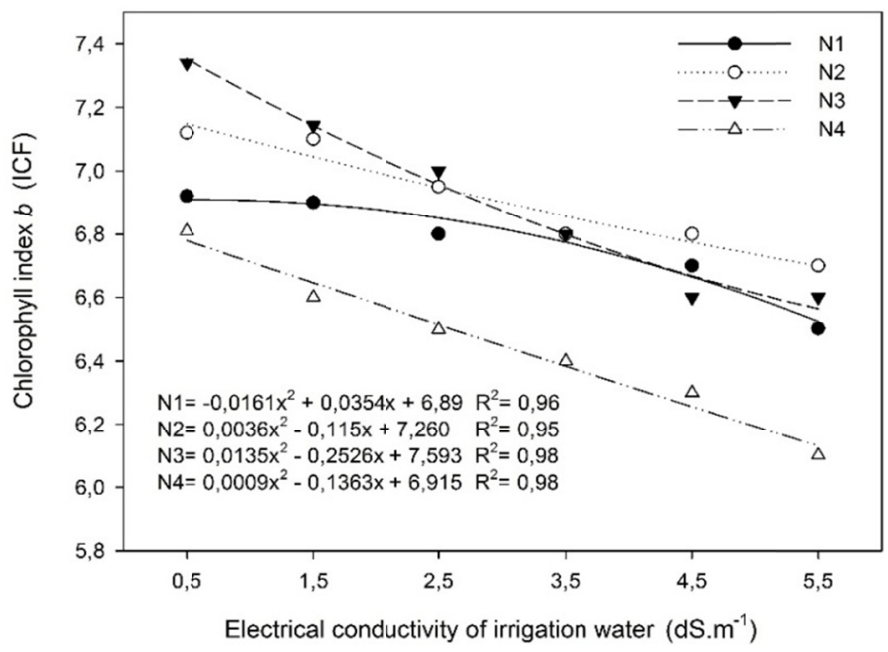

Figure 4. Chlorophyll index b under nitrogen fertigation to the $0(-)$, to the $10(---)$, to the $20(\cdots .$.$) and to the 30$ $(-\cdots-\cdot)$ days after emergence (DAE) in ornamental sunflower plants irrigated with Saline water

In the summary of the analyses of variance, shown in Table 3, it is observed that there was no significant effect of the interaction between Salinity and Fertigation for root length (RL), fresh mass of shoots (FMS), dry mass of shoots (DMS), fresh mass of roots (FMR) and total dry mass (TDM).

Table 3. Abstracts of the analysis of the variance for the Diameter of the Root, Root Length (CR), Chlorophyll $a$ (Cla), Chlorophyll $b(\mathrm{Clb})$, Total Chlorophyll (Clt), Fresh Mass of the Aerial Part (MFPA), Fresh Mass of the Root (MFR), Total Fresh Mass (MFT), Dry Mass of the Aerial Part (MSPA), Dry Mass of the Root (MSR), Total Dry Mass (MST), Mass of the Seeds (MS) And Mass of pseudostem (MC) of the ornamental sunflower plants (Helianthus annus L.) in function of the walter salinity of the irrigation in different times of nitrogenous fertirrigation

\begin{tabular}{|c|c|c|c|c|c|c|c|c|c|c|c|c|c|c|}
\hline \multirow{2}{*}{ SV } & \multirow{2}{*}{$\mathrm{DF}$} & \multicolumn{13}{|c|}{ Mean Square } \\
\hline & & $\mathrm{DC}$ & $\mathrm{CR}$ & $\mathrm{Cl} a$ & $\mathrm{Cl} b$ & $\mathrm{Cl} t$ & MFPA & MFR & MFT & MSPA & MSR & MST & MS & $\mathrm{MC}$ \\
\hline $\mathrm{S}$ & 5 & $69.16^{* *}$ & $1744.75^{* *}$ & $64.07^{* *}$ & $8.96^{\mathrm{ns}}$ & $94.25^{*}$ & $19586.33^{* *}$ & $1763.99^{* *}$ & $28461.59^{* *}$ & $1763.99^{* *}$ & $132.02^{* *}$ & $2745.74^{* *}$ & $80.48^{* *}$ & $422.98^{* *}$ \\
\hline $\mathrm{F}$ & 3 & $12.50^{* *}$ & $323.65^{* *}$ & $200.36^{* *}$ & $10.04^{\mathrm{nsb}}$ & $271.95^{* *}$ & $3544.20^{* *}$ & $81.75^{\mathrm{ns}}$ & $5671.35^{* *}$ & $81.75^{\mathrm{ns}}$ & $32.03^{* *}$ & $136.78^{\mathrm{ns}}$ & $15.14^{* *}$ & $28.62^{*}$ \\
\hline $\mathrm{S} \times \mathrm{F}$ & 15 & $7.91^{* *}$ & $64.67^{\mathrm{ns}}$ & $68.10^{* *}$ & $11.56^{* *}$ & $129.19^{* *}$ & $944.21^{\mathrm{ns}}$ & $38.65^{\mathrm{ns}}$ & $1635.67^{*}$ & $38.65^{\text {ns }}$ & $12.70^{*}$ & $45.50^{\mathrm{ns}}$ & $9.53^{* *}$ & $20.96^{*}$ \\
\hline $\mathrm{R}$ & 96 & 2.12 & 49.62 & 17.06 & 4.60 & 31.73 & 554.89 & 37.52 & 831.24 & 37.52 & 6.46 & 55.20 & 3.21 & 9.75 \\
\hline Total & 119 & - & - & - & - & - & - & - & - & - & - & - & - & - \\
\hline $\mathrm{CV}(\%)$ & - & 16.45 & 12.98 & 17.26 & 10.42 & 18.21 & 10.35 & 13.17 & 14.38 & 13.17 & 12.69 & 15.47 & 14.99 & 17.32 \\
\hline
\end{tabular}

Note. Salinity-ECa (S), Fertigation (F), Residue (R); CV = Coefficient of variation; ${ }^{\text {ns }}=$ not significant by the $\mathrm{F}$ test; $*$ and $* *=$ significant at 5 and $1 \%$ probability, respectively.

The plants showed a decrease in the total chlorophyll content as the electrical conductivity of irrigation water was increased (Figure 5). Salinity promotes a decrease in chlorophyll content in sensitive plants and an increase in tolerant plants (Jamil et al., 2007). The photosynthetic efficiency is also linked to the chlorophyll content of plants, affecting their growth and adaptability to different environments. This is due to unfavorable salinity conditions for their growth and development. In the case of nitrogen fertigation, the application at $20 \mathrm{DAE}$ provided a higher chlorophyll accumulation when compared to the other applications, where the fertigation 
performed at 30 DAE provided the lowest total chlorophyll contents. For Santos (2004), the reduction in chlorophyll synthesis occurs due to the effect of $\mathrm{NaCl}$ in promoting the reduction of aminolevulinic acid (ALA), precursor of protochlorophyll, which is converted to chlorophyll in the presence of light.

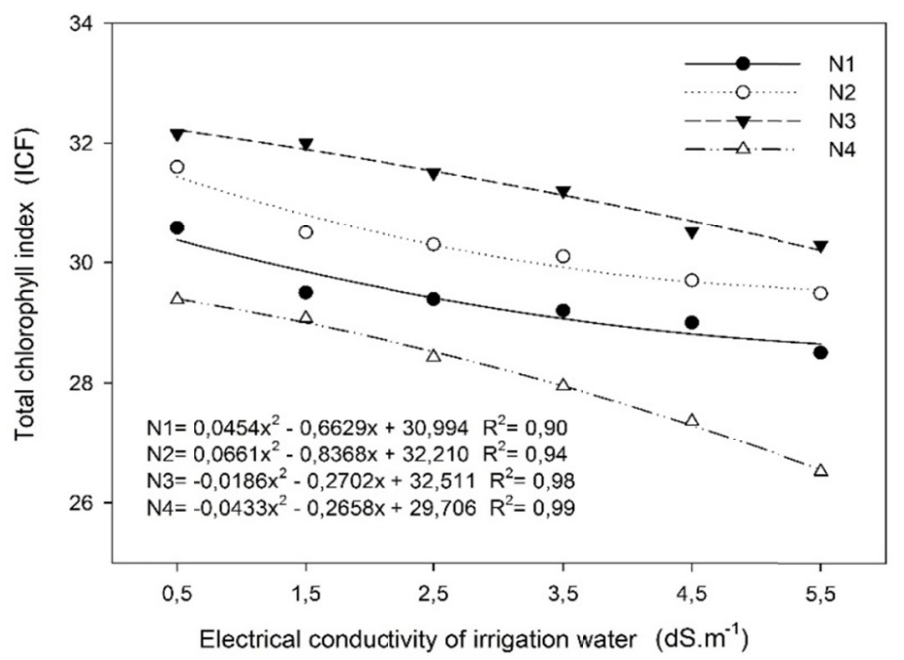

Figure 5. Total chlorophyll index under nitrogen fertigation to the $0(-)$, to the $10(---)$, to the $20(\cdots .$.$) and to the$ 30 (-..-.) days after emergence (DAE) in ornamental sunflower plants irrigated with Saline water

From the regression analysis, it was verified a reduction of the fresh mass of shoots (Figure 6) due to a higher concentration of $\mathrm{NaCl}$, that is, greater electrical conductivity in the water used for irrigation, influencing the development of the plant, since $\mathrm{Na}^{+}$has Ability to retain water, hindering its absorption by plants, increasing the toxicity of the solution and making it inadequate for the good development of the plant. These results corroborate Travassos et al. (2012), which point out that the fresh phytomass of shoots was affected by the salinity of the irrigation water in the variety Embrapa 122/V2000. The plants showed lower fresh mass of roots as the electrical conductivity of water was increased, with a reduction of $77 \%(25.2 \mathrm{~g})$ between ECa of 5.5 and $0.5 \mathrm{dS} \mathrm{m}^{-1}$ (Figure 6). According to Asch et al., (2000), high salt concentration in irrigation water or soil, caused mainly by the presence of $\mathrm{Na}^{+}$and $\mathrm{Cl}^{-}$ions, can lead to an interruption in the homeostasis of the water potential and ionic imbalance at the soil-plant interface and promote toxicity in the plant, altering its growth, besides promoting reduction in the absorption of nutrients. In relation to nitrogenous fertirrigation times, there was no significant difference for these variables.

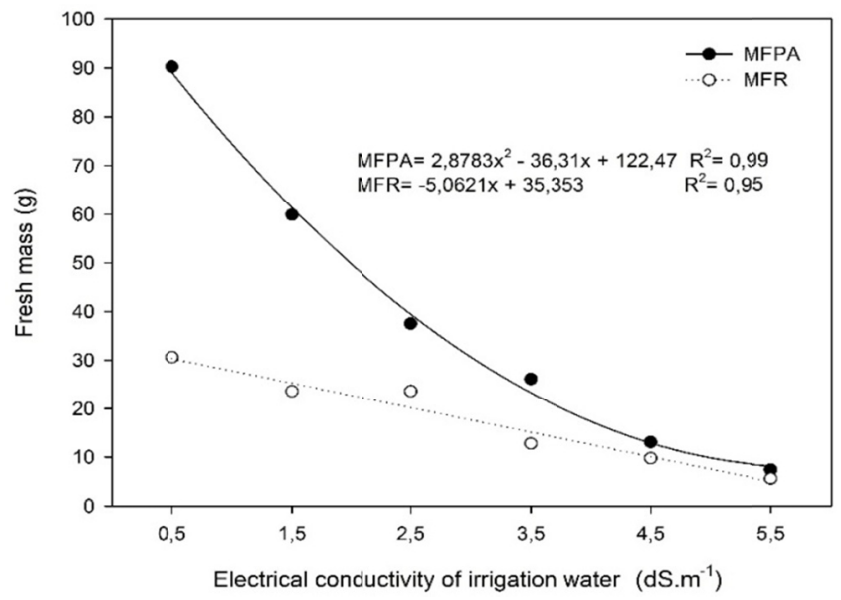

Figure 6. Fresh mass of aerial part and root of ornamental sunflower plants irrigated with saline water

Regarding the total fresh mass, there was a decrease with increasing ECa; notwithstanding, the nitrogen fertigation at 0 and $10 \mathrm{DAE}$ were more efficient when compared to the other applications. The application of 
fertirrigation at 30 DAE was the one that showed the lowest mass among the other applications (Figure 7). The growth inhibition may have been due in large part to the toxic effects of the salts absorbed by plants, the low osmotic adjustment capacity of the crop and the reduction of the total water potential caused by the increase in saline concentration (Lacerda et al., 2006; Silva et al., 2011).

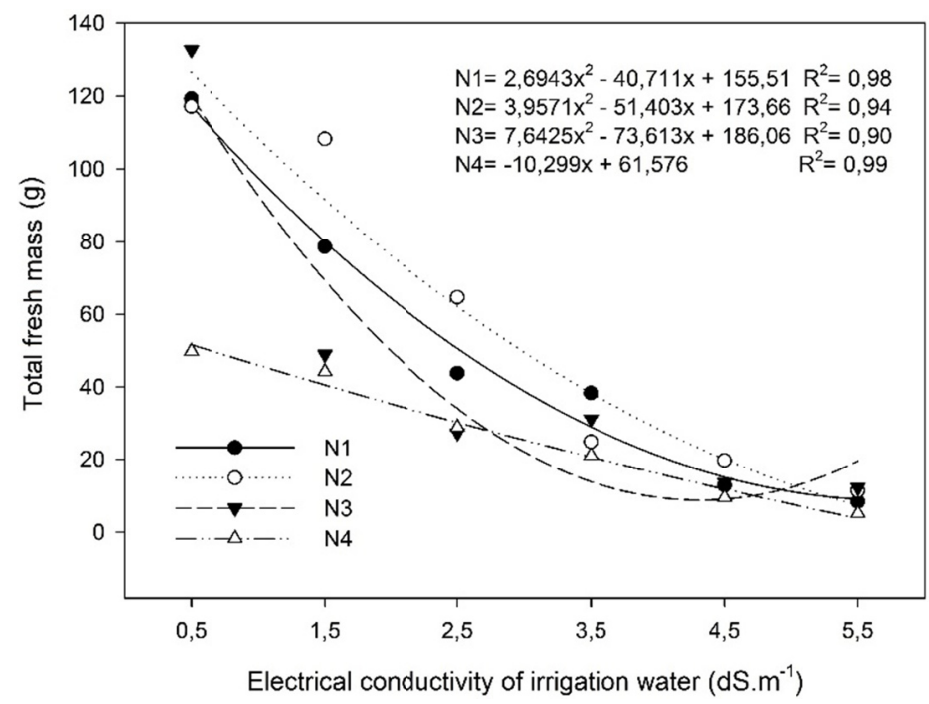

Figure 7. Total fresh mass of ornamental sunflower plants irrigated with saline water and nitrogen fertirrigation to the $0(-)$, to the $10(---)$, to the $20(\cdots .$.$) and to the 30(-. \cdot-\cdot)$ days after emergence (DAE)

DMS was affected by the conductivity of the irrigation water (Figure 8), providing a reduction of approximately $77 \%$ (23 g) between ECa of 5.5 and $0.5 \mathrm{dS} \mathrm{m}^{-1}$. There was no significant difference for treatments with nitrogen fertilization in this variable. This behavior may have occurred because all treatments received the same amount of nitrogen $\left(60 \mathrm{~kg} \mathrm{ha}^{-1}\right)$, but at different times. Results similar to this study were observed by Morais et al. (2011) and Silva et al. (2009) in sunflower plants, also recording a reduction in DMS when increasing salt concentrations were applied to irrigation water. For Flowers (2004), the growth inhibition of plants under salt stress can be explained by the decrease in the osmotic potential of the soil solution, in addition to the possibility of ionic toxicity, nutritional imbalance or both, due to excess accumulation of certain ions in plant tissues. Furthermore, plants tend to close the stomata to reduce water loss through transpiration, resulting in a lower photosynthetic rate, and contributing to reduced species growth under such stress.

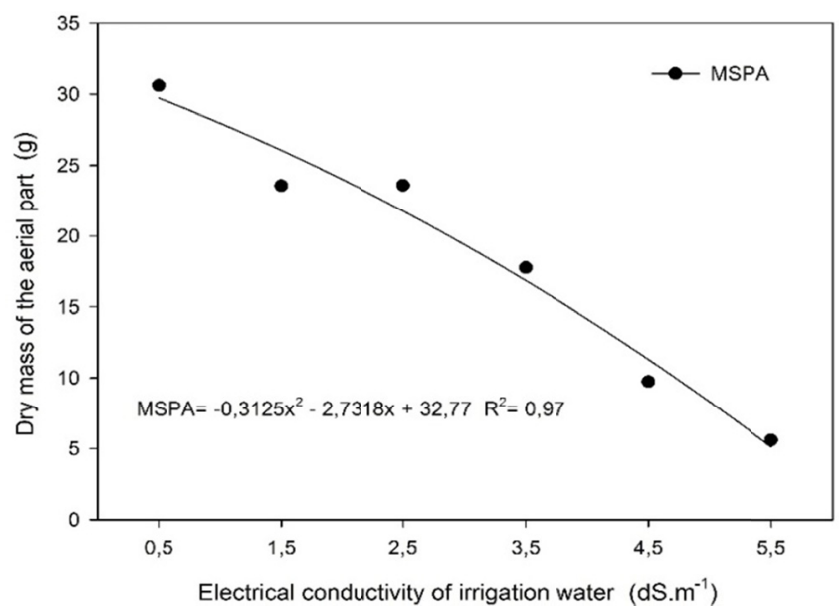

Figure 8. Dry mass of aerial part of the ornamental sunflower plants irrigated with saline water 
The dry mass of the root system was reduced by increasing the electrical conductivity of the irrigation water, however, the plants that received the nitrogen fertigation at 0 and 10 DAE presented a similar dry mass, standing out when compared to the other doses (Figure 9). Such evidence has been a classic behavior verified in other studies when plants are subjected to saline stress (Blanco et al., 2008; Medeiros et al., 2011; Maciel et al., 2012).

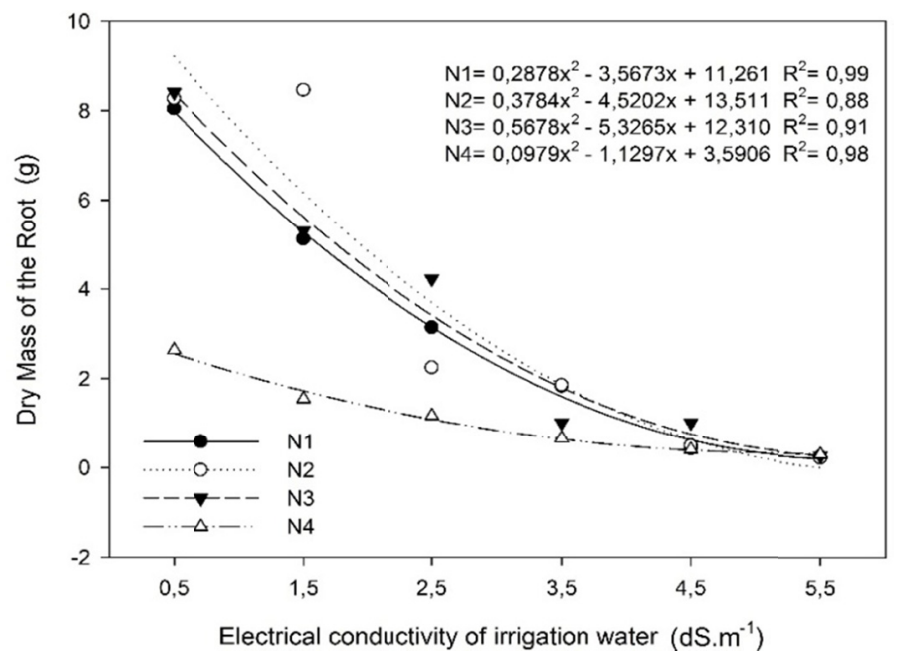

Figure 9. Dry mass of Root of the ornamental sunflower plants irrigated with saline water and nitrogen fertirrigation to the $0(-)$, to the $10(---)$, to the $20(\cdots \cdots)$ and to the $30(-\cdots-\cdot)$ days after emergence (DAE)

In Figure 10, it is observed that there was a decrease in the total dry mass of the sunflower plants as the electrical conductivity of the irrigation water was increased, with a reduction of $78 \%(31 \mathrm{~g})$ between ECa of 5.5 and $0.5 \mathrm{dS}$ $\mathrm{m}^{-1}$. These results resemble those of Silva et al. (2009), who observed a significant reduction in the total dry mass accumulation of plants, leaves, stems, roots and capitulums, besides changes in the leaf area and height of ornamental sunflower plants with increased electrical conductivity (EC) of irrigation water. The decrease in leaf area, leaves, stem, roots and capitulums is due to the osmotic and water stresses that are a consequence of the saline stress in the root environment, which may, according to Ayers and Westcot (1999), promote physiological imbalance to the plants.

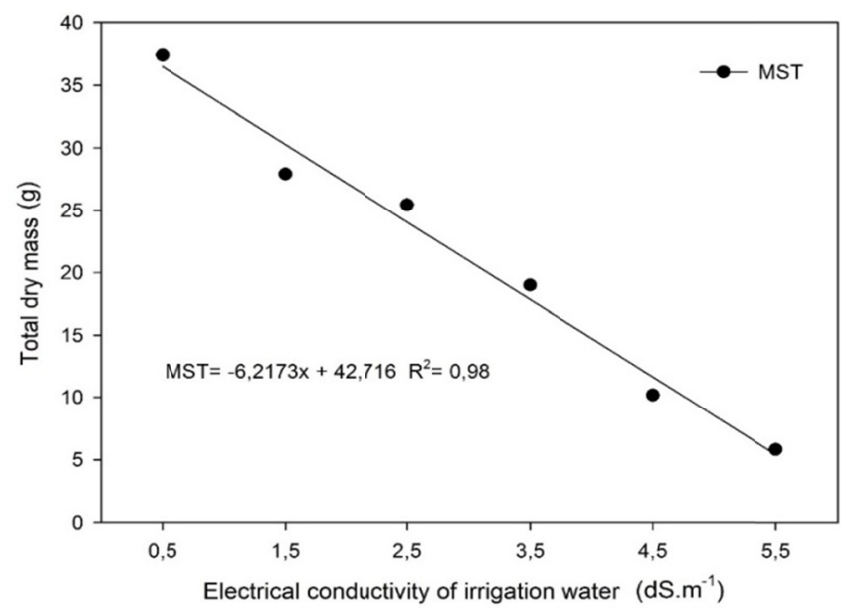

Figure 10. Total dry mass of ornamental sunflower plants irrigated with saline water

Seed mass (Figure 11) was significantly affected by the unit increase of the electrical conductivity of water, where reductions were observed in all $\mathrm{ECa}$, being related to the sunflower sensitivity to irrigation water salinity. Salinity affects not only growth, but also crop production and fruit quality, with symptoms similar to those of water stress (Tester \& Davenport, 2003). The plants that received nitrogen fertigation stood out from the control, showing a greater dry mass accumulation in the seeds. Lobo, Grassi Filho, and Coelho (2012), studying the 
effect of nitrogen fertilization on sunflower crop, found similar effect for seed mass. Information on the effect of salinity of water and/or soil on production quality is scarce; in general, soil salinity, caused by irrigation with saline water or by the combination of water, soil and crop management factors, may result in a reduction both in the number of fruits and in the fruit and seed weight, directly influencing production (Rhoades et al., 2000).

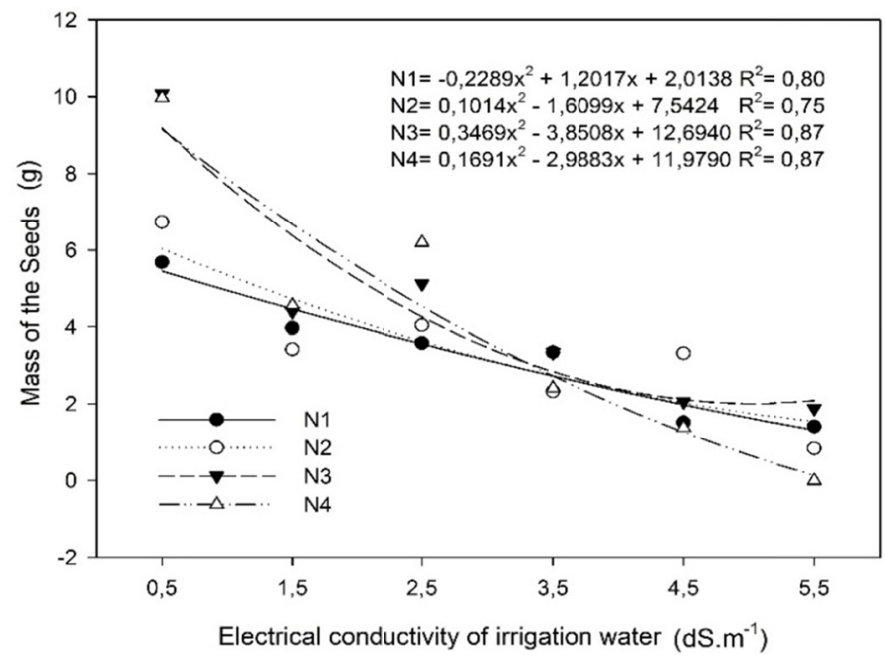

Figure 11. Seed mass of ornamental sunflower plants irrigated with saline water and nitrogen fertilization to the $0(-)$, to the $10(---)$, to the $20(\cdots .$.$) and to the 30(-. \cdot-\cdot)$ days after emergence (DAE)

The dry mass of the capitulum was negatively affected by the levels of salinity contained in irrigation water. As the electrical conductivity of the water increased, there was a decrease in the dry mass of the capitulum, as can be observed in Figure 12. According to Guedes Filho et al. (2015), increased irrigation water salinity significantly affected the dry phytomass production of the capitulum, with a decrease of $42.3 \%(36.6$ to $21.1 \mathrm{~g}$ plant $^{-1}$ ) with an increase in the electrical conductivity of irrigation water from 0.15 to $4.5 \mathrm{dS} \mathrm{m}^{-1}$. Ribeiro et al., (2016) obtained a reduction of $54.02 \%(24.2 \mathrm{~g})$ of the dry phytomass of the capitulum in plants irrigated with water presenting ECa of $4.5 \mathrm{dS} \mathrm{m}^{-1}$, when compared to the controls (ECa of $0.5 \mathrm{dS} \mathrm{m}^{-1}$ ).

In relation to nitrogen fertigation, the one performed at 30 DAE provided better results for the mass of the capitulum, when compared to the other applications. Guedes Filho et al. (2015) also observed that the phytomass of the capitulum, when the plant was fertilized with nitrogen, was superior to the control at all levels of irrigation water salinity. The nitrogen fertilization results for phytomass growth are in line with those obtained by Munir, Malik, and Saleem (2007).

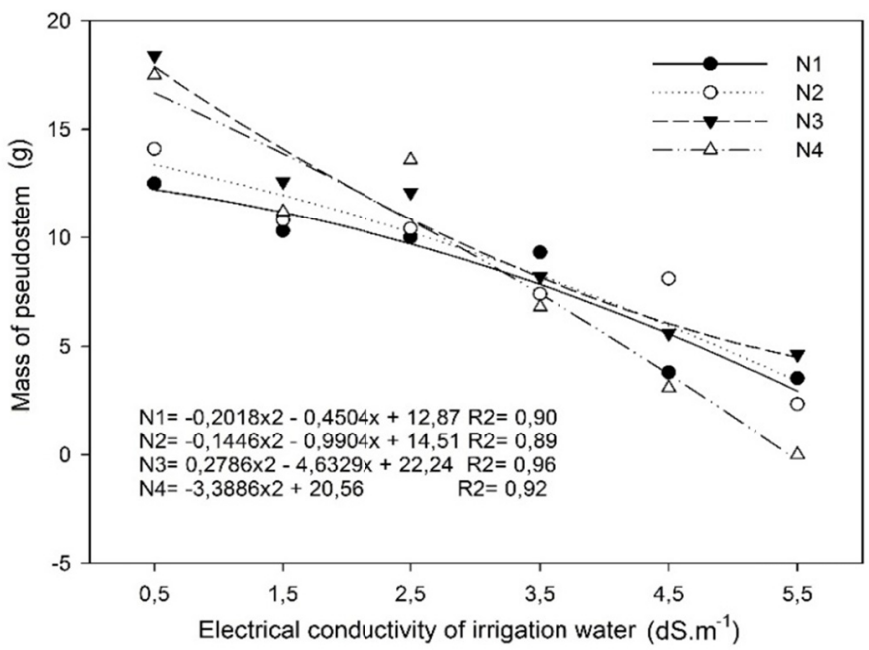

Figure 12. Dry mass of pseudostem of the ornamental sunflower plants irrigated with saline water and nitrogen fertilization to the $0(-)$, to the $10(---)$, to the $20(\cdots \cdots)$ and to the $30(-.-\cdot)$ days after emergence (DAE) 


\section{Conclusions}

Irrigation water salinity negatively affects the growth variables, chlorophyll contents, phytomass and productivity evaluated, where the conductivity of $5.5 \mathrm{dS} \mathrm{m}^{-1}$ provides higher losses.

Fertigation at 10 days after emergence provided greater plant diameter, not demonstrating efficiency in the other analyzed variables.

Nitrogen fertigation at $20 \mathrm{DAE}$, in general, shows increased chlorophyll a, b and total chlorophyll content in sunflower plants.

Fertigation at 30 days after emergence was less efficient when compared to the other application times, and it was not recommended for sunflower cultivation under the conditions of the experiment.

\section{References}

Andrade, L. O., Gheyi, H. R., Nobre, R. G., Dias, N. S., \& Nascimento, E. C. S. (2012). Qualidade de flores de girassóis ornamentais irrigados com águas residuária e de abastecimento. Idesia, 30(2), 19-27. https://doi.org/10.4067/S0718-34292012000200003

Banzatto, D. A., \& Kronka, S. N. (2006). Experimentação agrícola (p. 247). Jaboticabal: FUNEP.

Costa, M. E., Morais, F. A., Souza, W. C. M., Gurgel, M. T., \& Oliveira, F. H. T. (2013). Estratégias de irrigação com água salina na mamoneira. Revista Ciência Agronômica, 44(1), 34-43. https://doi.org/10.1590/S180666902013000100005

Curti, G. L., Martin, T. N., Ferronato, M. L., \& Benin, G. (2012). Girassol ornamental: Caracterização, pós-colheita e escala de senescência. Revista de Ciências Agrárias, 35(1), 240-250.

Garcia, G. O., Ferreira, P. A., Miranda, G. V., Neves, J. C. L., Moraes, W. B., \& Santos, D. B. (2007). Teores foliares dos macronutrientes catiônicos e suas relações com sódio em plantas de milho sob estresse salino. Idesia, 25(5), 93-106. https://doi.org/10.4067/S0718-34292007000300010

Grieve, C. M., \& Poss, J. A. (2010) Response of ornamental sunflower cultivars 'sunbeam' and 'moonbright' to irrigation with saline wastewaters. Journal of Plant Nutrition, 33, 1579-1592. https://doi.org/10.1080/ 01904167.2010.496883

Guedes Filho, D. H., Santos, J. B., Gheyi, H. R., Cavalcante, L. F., \& Santos Junior, J. A. (2015). Componentes de produção e rendimento do girassol sob irrigação com águas salinas e adubação nitrogenada. Irriga, 20(3), 514-527. https://doi.org/10.15809/irriga.2015v20n3p514

Houle G. (2001). The effect of salinity on different developmental stages of an endemic annual plant, aster laurentianus (asteraceae). American Journal of Botan, 88(1), 62-67. https://doi.org/10.2307/2657127

Ibarra, M., \& Maiti, R.K. (1995). Biochemical mechanism in glossy sorghum lines for resistance to salinity stress. Journal Plant Physiology, 146(4), 515-519. https://doi.org/10.1016/S0176-1617(11)82017-1

Ivanoff, M. E. A. (2010). Formas de aplicação de nitrogênio em três cultivares de girassol na savana de roraima. Revista ciência agronômica, 4l(3), 319-325. http://dx.doi.org/10.1590/S1806-66902010000300001

Jamil, M. K., Rehman, S. U., Lee, K. J., Kim., J. M., Kim., H. S., \& Rha, E. S. (2017). Salinity reduced growth ps2 photochemistry and chlorofhyll content in radish. Scientia Agrícola, 64(2), 111-118. https://doi.org/ $10.1590 / \mathrm{S} 0103-90162007000200002$

Lobo, T. F., Grassi F. H., \& Coelho, H. A. (2012). Efeito da adubação nitrogenada na produtividade do girassol. Cientifica, 40(1), 59-68.

Munir, M. A., Malik, M. A., \& Saleem, M. F. (2007). Impact of integration of crop manuring and nitrogen application on growth, yield and quality of spring planted sunflower (Helianthus annuus L.). Pakistan Journal Botany, 39(2), 441-449.

Rhoades, J. D., Kandiah, A., \& Mashali, A. M. (2000). Uso de águas salinas para produção agrícola (p. 117). Estudos da fao, irrigação e drenagem. Campina Grande: UFPB.

Ribeiro, P. H. P., Gheyi, H. R., Uyeda, C. A., Teixeira, M. B., Soares, F. A. L., \& Dias, N. S. (2016). Taxa de crescimento e produção de girassol irrigado com água salina sob doses de nitrogênio. Irriga, 233-247. https://doi.org/10.15809/irriga.2016v1n1p233-247 
Rodrigues, E. J. R., Pivetta, K. F. L., Castilho, R. M. M., Mattiuz, C. F. M., Batista, G. S., \& Grossi J. A. S. (2012). Girassol. In P. D. O. Paiva, \& E. F. A. Almeida (Eds.), Produção de flores de corte (pp. 403-440). UFLA, Lavras, MG.

Russo, D. (2005). Physical Aspects of Soil Salinity. Encyclopedia of Soils in the Environment. Elsevier, Oxford, UK. https://doi.org/10.1016/B0-12-348530-4/00529-4

Santos Júnior, J. A., Gheyi, H. R., Cavalcante, A. R., Dias, N. S., \& Medeiros, S. S. (2016). Produção e pós-colheita de flores de girassóis sob estresse salino em hidroponia de baixo custo. Engenharia Agrícola, 36(3), 420-432. https://doi.org/10.1590/1809-4430-Eng.Agric.v36n3p420-432/2016

Santos, C. V. (2004). Regulation of chlorophyll biosynthesis and degradation by salt stress in sunflower leaves. Scientia Horticulturae, 103, 93-99. https://doi.org/10.1016/j.scienta.2004.04.009

Santos, D. B. (2005). Efeitos da salinidade sobre características químicas do solo, aspectos nutricionais, fisiológicos e de produção no feijoeiro irrigado (p. 78). Viçosa: UFV.

Silva, A. R. A., Bezerra, F. M. L., Sousa, C. C. M., Pereira Filho, J. V., \& Freitas, C. A. S. (2011). Desempenho de cultivares de girassol sob diferentes lâminas de irrigação no vale do curu, ce. Revista Ciência Agronômica, 42(1), 57-64. https://doi.org/10.1590/S1806-66902011000100008

Silva, T. G. F. D., Zolnier, S., Grossi, J. A. S., Barbosa, J. G., Moura, C. R. W., \& Muniz, M. A. (2009). Crescimento do girassol ornamental cultivado em ambiente protegido sob diferentes níveis de condutividade elétrica de fertirrigação. Revista ceres, 56(5), 602-610.

Taiz, L., \& Zeiger, E. (2012). Fisiologia vegetal (5th ed., p. 954). Porto Alegre: Artmed.

Travassos, K. D., Soares, F. A. L., Gheyi, H. R., Silva, D. R. S., Nascimento, A. K. S., \& Dias, N. S. (2011). Produção de aquênio do girassol irrigado com água salobra. Revista Brasileira de Engenharia Agrícola e Ambiental, 15(4), 371-376. https://doi.org/10.1590/S1415-43662011000400007

Wong, V. N. L., Dalal, R. C., Greene, R. S. B. (2008). Salinity and sodicity effects on respiration and microbial biomass of soil. Biologia e Fertilidade dos Solos, 44, 943-953. https://doi.org/10.1007/s00374-008-0279-1

Zobiole, L. H. S., Castro, C., Oliveira, F. A., \& Junior, A. O. (2010). Marcha de absorção de macronutrientes na cultura do girassol. Revista Brasileira de Ciência do Solo, 34(02), 425-433. https://doi.org/10.1590/S010006832010000200016

\section{Copyrights}

Copyright for this article is retained by the author(s), with first publication rights granted to the journal.

This is an open-access article distributed under the terms and conditions of the Creative Commons Attribution license (http://creativecommons.org/licenses/by/4.0/). 